\title{
ANALISIS PERKULIAHAN ANATOMI MENGGUNAKAN MEDIA BERBASIS APLIKASI ANATOMY ILLUSTRATION PADA MAHASISWA PENDIDIKAN JASMANI, KESEHATAN DAN REKREASI STKIP SYEKH MANSHUR SAAT COVID-19
}

\author{
Devaron Suardi ${ }^{1}$, Idris Supriadi ${ }^{2}$, Ira Asyura ${ }^{3}$ \\ Program Studi Pendidikan Jasmani, Kesehatan, dan Rekreasi, STKIP Syekh Manshur ${ }^{1,2}$ \\ Pendidikan Matematika, STKIP Syekh Manshur ${ }^{3}$ \\ E-mail: devaron_suardi@stkip.syekhmanshur.ac.id
}

\begin{abstract}
ABSTRAK
Penelitian ini bertujuan untuk menganalisis perkuliahan anatomi menggunakan media berbasis aplikasi Anatomy Illustration. Media atau aplikasi yang dipakai dalam perkuliahan sangat diperlukan untuk meningkatkan minat dan kreatifitas mahasiswa dalam memahami materi yang ada dalam perkuliahan anatomi tubuh manusia. Teknik pengambilan sampel yang digunakan pada penelitian ini adalah teknik total sampling dimana populasi digunakan langsung sebagai sampel yaitu mahasiswa semester 3 program studi pendidikan jasmani, kesehatan, dan rekreasi yang berjumlah 40 mahasiswa. Aktivitas dalam analisis data kualitatif yaitu reduksi data, penyajian data, verifikasi data atau penarikan kesimpulan. Metode yang digunakan dalam penelitian ini dengan menggunakan metode kualitatif yaitu penelitian deskriptif kualitatif dengan menggunakan teknik survey. Instrumen penelitian yang digunakan adalah angket, observasi, dan dokumentasi. Teknik analisis data yang menggunakan model Miles and Huberman. Angket diberikan secara online dalam format google form. Perkuliahan Anatomi menggunakan media berbasis aplikasi Anatomy illustration saat Covid-19 memberikan respon sangat positif ditinjau dari aspek daya tarik (82\%), positif ditinjau dari aspek kemudahan penggunaan (74\%), efisiensi waktu (74\%), dan manfaat dari media berbasis aplikasi Anatomy Illustration (76\%). Kesimpulan dari penggunaan media berbasis aplikasi Anatomy Illustration adalah memberikan respon positif untuk perkuliahan anatomi.
\end{abstract}

Kata Kunci: Anatomy Ilustration; Olahraga; Covid-19

\begin{abstract}
This research aims to analyze anatomy lectures using media based application Anatomy Illustration. Media or applications used in lectures are needed to increase the interest and creativity of students in understanding the material in the anatomy lectures of the human body. The sampling technique used in this study is a total sampling technique where the population is used directly as a sample, namely students of semester 3 of physical education, health, and recreation study programs that numbered 40 students. Activities in qualitative data analysis are data reduction, presentation, verification or conclusion withdrawal. The method used in this study using qualitative methods is qualitative descriptive research using survey techniques. The research instruments used are questionnaires, observations, and documentation. Data analysis techniques using Miles and Huberman models. The questionnaire is provided online in google form. Anatomy lectures using anatomy illustration application-based media when Covid-19 gave a very positive response in terms of attractiveness (82\%), ease of use (74\%), time efficiency (74\%), and the benefits of anatomy illustration application-based media (76\%). The conclusion of the use of media based on the Anatomy Illustration application is to give a positive response to anatomy lectures.
\end{abstract}

Keywords: Anatom Illustration; Sports; Covid-19

Dipublikasikan Oleh :

UPT Publikasi dan Pengelolaan Jurnal

Universitas Islam Kalimantan Muhammad Arsyad Al-Banjari Banjarmasin 


\section{PENDAHULUAN}

Perkuliahan anatomi merupakan salah satu mata kuliah wajib pada Program Studi Pendidikan Jasmani Kesehatan dan Rekreasi di STKIP Syekh Manshur. Perkuliahan anatomi merupakan pondasi dasar dalam perkuliahan berkelanjutan, dan juga menjadi persyaratan utama bagi mahasiswa untuk melanjutkan matakuliah selanjutnya, seperti fisiologi, massase, fisiologi olahraga, P3K cidera olahraga dan lain-lain. Tuntutan yang mengharuskan mahasiswa untuk memahami seluruh aspek, komponen penyusun dan cara kerja dari tulang, otot, dan sendi untuk melakukan sebuah gerakan. Dengan kemampuan dalam menganalisa kinerja otot tulang dan sendi akan memudahkan mahasiswa untuk melanjutkan perkuliahan pendalaman, recovery dalam perkuliahan massase, dan melakukan pertolongan pertama pada cidera olahraga yang bisa diaplikasikan dalam kehidupan sehari-hari.

Perkuliahan anatomi banyak sekali menggunakan alat peraga atau media yang digunakan baik dari segi konvensional sepeti menekin rangka atau otot dan menggunakan berbagai macam aplikasi yang didukung dengan oleh basis teknologi yang memadai. Proses pembelajaran pun masih sangat beragam, ada yang hanya menggunakan media konvensional berupa manekin dan disertai dengan diktat atau modul. Perkuliahan anatomi sangat membutuhkan alat peraga dan media yang bertujuan untuk meningkatkan pemahaman mahasiswa terhadap penyusun, komponen, tujuan dan cara kerja dari tulang, otot dan sendi. Metode yang sering digunakan adalah metode konvensional dimana perkuliahan menggunkan alat peraga dan visualisasi dimana hal ini dinilai lebih efektif, namun berbanding terbalik pada saat perkuliahan secara daring. Dalam pembelajaran daring mahasiswa kekurangan alat peraga dikarenakan harga dari alat peraga atau manikin yang cukup mahal. Dengan demikian perkuliahan akan sedikit terhambat dan akan mempengaruhi hasil atau output yang ingin dicapai.

Peningkatan kualitas dalam pelaksanakan perkuliahan merupakan salah satu tugas dari seorang dosen pengampu. Perkuliahan harus selalu berjalan dengan kondusif dengan segala kendala yang ada termasuk dengan pembelajaran yang berbasis dalam jaringan secara keseluruhan ataupun Blindeed Learning, dimana pertemuan dibagi menjadi $30 \%$ dengan cara tatap muka dan $70 \%$ secara online atau dalam jaringan. Dan peraturan pemerintah yang sering mendadak yang dikarenakan situasi yang mendesak. Dengan demikian dosen dan mahasiswa harus dituntut menemukan media yang sesuai dengan perkuliahan yang ditempuh sesuai dengan kondisi mengikuti peraturan pemerintah.

Kreatifitas dalam melakukan perkuliahan seperti saat pandemi sekarang ini sangat dibutuhkan baik dosen ataupun mahasiswa. Hal ini dikarenakan pembelajaran seringkali dilakukan secara online yang menutut mahasiswa dan dosen untuk mendapatkan sumber dan contoh dari luar dengan menggunakan media seperti aplikasi yang mendukung dalam perkuliahan anatomi pada khususnya. Diperlukan perhatiah khusus terhadap tingkat keberhasilah perkuliahan dengan menggunakan berbagai media yang ada dan tersedia dengan tidak mengesampingkan kebutuhan dan kemampuan mahasiswa di masa pandemi. Dan ada juga yang menggunakan teknologi terbaru yang berupa gambar, video bahkan media yang berbasis aplikasi, dengan tujuan lebih mudah untuk mengenal dan memahami secara lebih terperinci lagi dan bisa dugunakan kapanpun.

Matakuliah dalam perkuliahan anatomi dalam perkuliahan di STKIP Syekh Manshur secara keseluruhan membahas mengenai beberapa komponen dalam tubuh manusia yang terdiri dari srtuktur dangka dan otot pada manusia. Secara keseluruhan mahasiswa harus bisa menguraikan apasaja yang terdapat pada strukutur tulang dan otot meliputi bagian, fungsi struktur, jaringan, pelekat, penghubung dari otot dan rangka. Anatomi merupakan salah satu matakuliah yang bersifat wajib di tempuh leh setiap mahasiswa di program studi pendidikan olahraga di STKIP Syekh Manshur. Matakuliah ini secara keseluruhan mempelajari tentang struktur dan fungsi dari tubuh baik itu tulang, otot dan sendi yang terdapat dalam tubuh manusia. Menurut KBBI Edisi V, anatomi adalah ilmu yang melukiskan letak dan hubungan bagian-bagian tubuh manusia (Depdikbud, 2016). Bisa diartikan jika anatomi adalah suatu ilmu yang menggambarkan bentuk, letak dan penghubung tubuh dari manusia secara terpisah yang bertujuan untuk lebih mudah untuk dipahami.

Anatomi adalah ilmu yang mempelajari bentuk dan susunan tubuh yang diperoleh dengan cara menguraikan tubuh melalui potongan-potongan bagian tubuh dan bagaimana hubungan organ tubuh satu dengan lainnya (Putri et al., 2016). Dengan konsep memisahkan system menjadi bagian-bagian kecil bertujuan agar struktur tulang dan otot bisa dipelajara dengan lebih detail lagi, karena diseluruh tubuh manusia tidak luput dari tulang dan otot. Perkuliahan anatomi bertujuan untuk meningkatkan kemampuan mahasiswa terhadap komponen, bentuk, fungsi, letak penghubung dan sifat dari tulang dan otot, yang memiliki fungsi utama sebagai alat gerak aktif pada tubuh manusia.

Dipublikasikan Oleh : 
Senada dengan pernyataan diatas, Pearce mengemukakan, anatomi adalah ilmu yang mempelajari susunan tubuh dan hubungan bagian-bagian tubuh satu sama lain (Pearce, 2016). Anatomi merupakan suatu ilmu yang mempelajari bagian dalan (internal) dan Luar (external) dari struktur tubuh manusia dan hubungan fisiknya dengan bagian tubuh lainnya (Wahyuningsih, H. P., \& Kusmiyati, 2017). Jadi dapat ditarik kesimpulan ilmu anatomi adalah sutu cabang ilmu yang mempelajari tentang struktur alat penggerak tubuh manusia yang dikaji terpisah dan dibahas secara menyeluruh baik itu internal dan eksternal, dan seluruh komponen penghubung dari potongan-potongan yang terdapat di dalam bagian tubuh manusia. Hal ini bertujuan untuk memahami konsep bagian tubuh secara mendasar sari segala aspek pendukung untuk terjadinya suatu gerakan yang normal.

Media merupakan salah satu sarana yang penting dalam melakukan pembelajaran, hal ini dikarenakan dengan menggunakan media yang tepat diharapkan dapat miningkatkan hasi dari pembelajaran secara bertahap yang disesuaikan dengan kebutuhan dan perkembangan teknologi. Media merupakan semua bentuk perantara yang digunakan oleh manusia untuk menyampaikan atau menyebarkan ide, gagasan, atau pendapat sehingga bisa sampai kepada penerima atau yang dituju (Arsyad, 2011). Media yang digunakan bisa berupa miniatur, replika, gambar, video, dan aplikasi. Seiring dengan perkembangan teknologi yang sangat pesat dapat dimanfaatkan untuk mengembangkan dunia Pendidikan termasuk sebagai penunjang pembelajaran (Asyura \& Dewi, 2020).

Media pembelajaran meliputi perangkat keras seperti buku, dan alat peraga, perangkat lunak yang bebasis penggunaan aplikasi baik itu dari computer ataupun aplikasi dari smartphone. Penggunaan buku kedokteran sebagai sumber belajar memiliki dampak negatif antara lain mahasiswa terkadang mengalami kesulitan dalam memahami materi (Miharja, 2015). Media bertujuan untuk mempermudah seseorang dalam menyampaikan keinginan sesuai dengan tujuan yang akan dicapai. Berkenaan dengan perkembangan teknologi pembelajaran, peranan media menjadi sangat penting. Pemilihan media yang tepet merupakan salah satu peranan dosen yang didasari oleh karaketistik dari mahasiswa, berdasarkan dari analisis kebutuhan dan karakteristik dari mahasiswa dosen bisa menentukan dan menerapkan media yang sesuai dengan tujuan dari perkuliahan. Memilih media yang tepat dan melakukan pemilihan itu berdasarkan teknik dan memahami Langkah-langkah yang benar (Mahnun, 2012).

Perkembangan teknologi sekarang ini membuat sarana atau media belajar beradaptasi dan menyesuaikan keadaan (Wanasuria et al., 2020). Pemilihan media yang sesuai dengan kebutuhan dan karakteristik menjadi pondasi utama untuk meningkatkan kualitas peembelajaran. Denang pemilihan yang tepat dan langkah -langkah yang sesuai dan penenmpatan yang sesuai dengan porsi nya maka diduga akan menigkatkan efektifitas dalam pembelajaran dan menjadikan pembelajaran tidak monoton. Hal ini brtujuan untuk menarik minat dasi peserta didik untuk mengikuti perkuliahan yang biasanya lebih cepat merasa bosan jika menggukana metode atau media konvensional.

Anatomy Illustration merupakan salah satu media yang berbasis aplikasi PC. Aplikasi ini diciptakan oleh Zubair Arif diproduksi oleh Paksoft Media Studio pada tahun 2009. Aplikasi ini berisis tentang tubuh secara keseluruhan, dan dibagi menjadi beberapa bagian sesuai dengan system yang ada didalam tubuh manusia, seperti system rangka, otot, system pencernaan, pernafasan, urinary, dan lain-lain. Aplikasi ini sangat menunjang dalam prosesperkuliahan yang membutuhkan penjelasan tentang struktur dan fungsi dari organ yang ada dalam tubuh. Dengan penjelasan melalui aplikasi secara tidak langsung mahasiswa akan mempertajam kemampuan berbahasa Inggirs, hal ini dikarenakan seluruh penjelasan dan pengertian dalam aplokasi menggunakan Bahasa Inggris. Berikut tampilan beranda pada anatomy illustration.

Dipublikasikan Oleh :

UPT Publikasi dan Pengelolaan Jurnal

Universitas Islam Kalimantan Muhammad Arsyad Al-Banjari Banjarmasin 


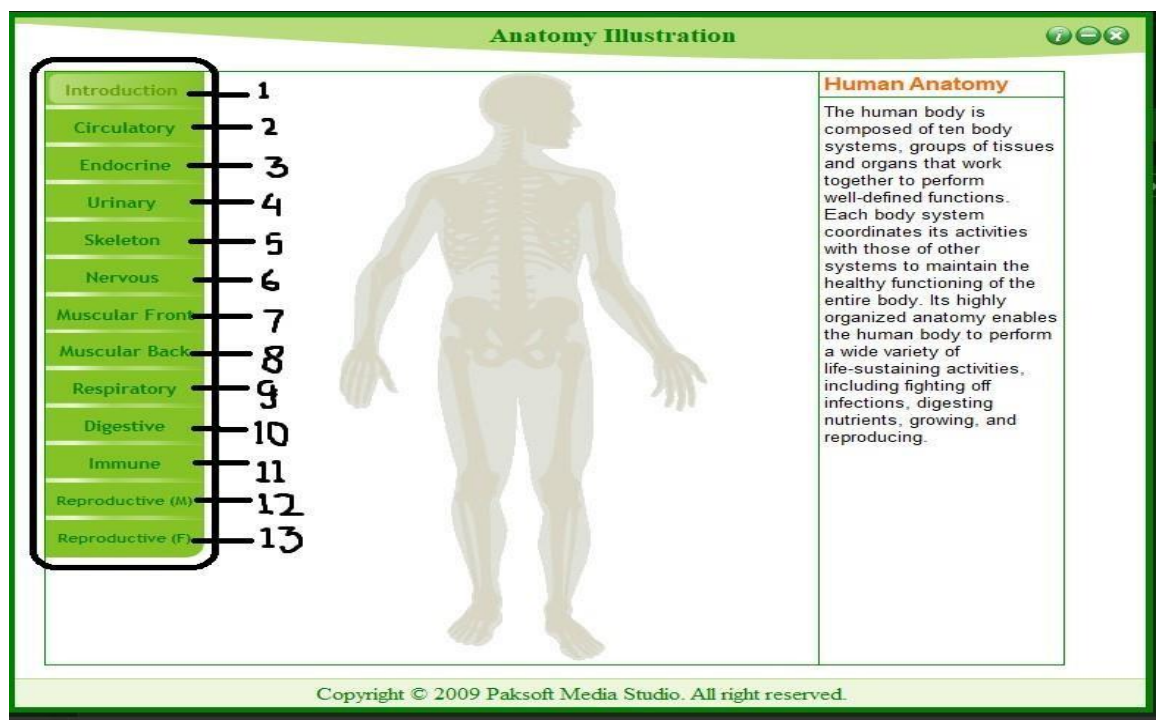

Gambar 1. Tampilan Beranda Anatomy Illustration

Layer beranda menyediakan beberapa menu pilihan yang bisa digunakan sesuai dengan kebutuhan dari pengguna. Bahasa yang digunakan dalam aplikasi adalah Bahasa Inggris, main menu berada disebelah kanan yang bisa dioperasikan dengan cara di klik. Setelah dipilih sesuai dengan keinginan maka akan ada tampilan dari organ di bagian tengan dan penjelasan pada layer bagian kiri, seperti gambar berikut :

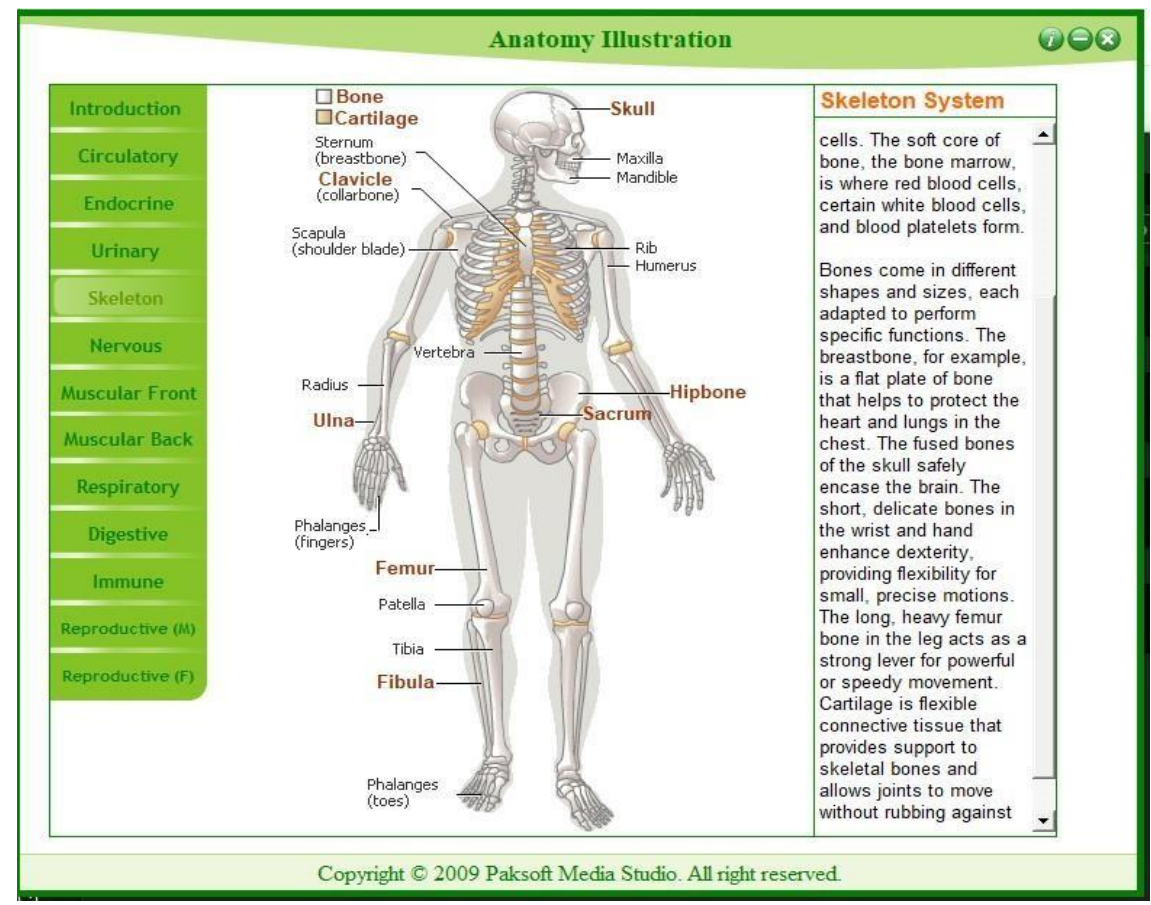

Gambar 2. Main Menu Sketelon

Dilayar bagian tengah ada tampilan yang menggambarkan sketelon atau rangka dari manusia dan juga terdapat nama-nama dari seriap bagiannya, jika nama pada bagia tersebut dipilih atau diklik maka akan muncul vocabulary atau Glorasium. Hal ini berguna untuk memberikanpenjelasan secara rici tentang apa yang akan dipilih oleh pengguna, seperti gambar berikut : 


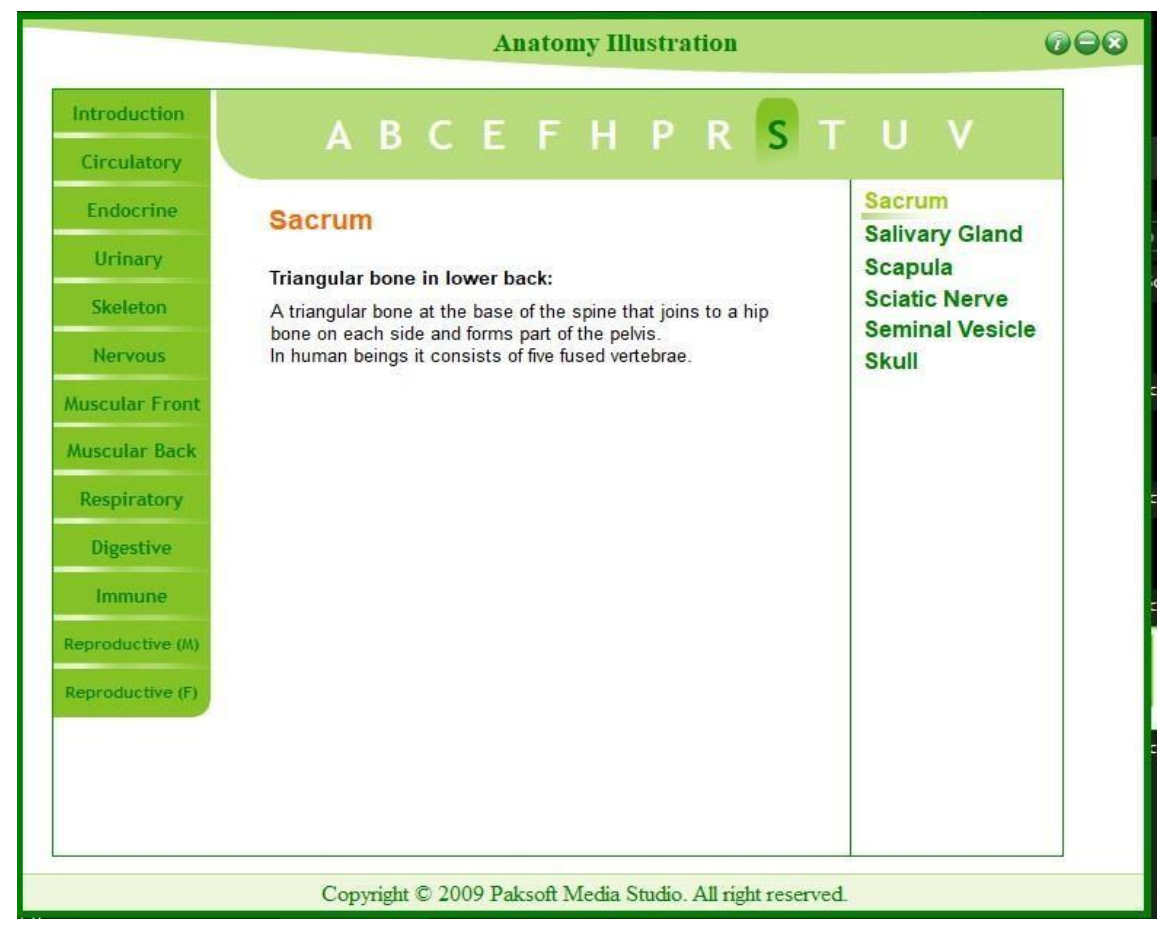

Gambar 3. Tampilan Lanjutan dari Pemilihan Menu

Dengan tampilan yang terdapat pada aplikasi anatomy illustration, dapat menjadikan perkulihan anatomi menjadi menarik dan interaktif. Mahasiswa dapat mengakses menu yang disediakan dan disesuaikan dengan kebutuhan perkuliahan yang akan dilakukan. Dengan demikian motivasi mahasiswa pada perkuliahan anatomi dan mempelakari struktur dan bentuk anatomi semakin meningkat sehingga hasil yang diinginkan dari proses perkuliahan tercapai. Setiap manusia pasti membutuhkan motivasi dalam hidupnya, meskipun jenis dan tingkatanya berbeda. Jika tidak adanya motivasi tentu manusia tidak akan dapat berbuat apa-apa, karena motivasilah yang menggerakan tingkah laku manusia (Khilmi et al., 2021).

Motivasi belajar sangat diperlukan terutama pada perkuliahan anatomi. Perkuliahan anatomi memiliki komponen yang bersifat abstrak dan berada pada tubuh manusia. Untuk itu, sangat diperlukan alat peraga dan media yang dapat menjadi pendukung dalam memahami matri dari anatomi. Adapun output dari perkuliahan anatomi ini adalah, mahasiswa dapat memahami dan mengingat letak dan struktur tubuh, apalagi bagi seorang atlet, penting dalam memahami struktur tubuh terutama saat pertandingan, untuk mengurangi resiko cedera diarea-area tertentu.

State of the art merupakan salah satu penilaian tambah dalam kebaharuan penelitian. Hal ini bertujuan unutk meningkatkan penelitian yang berjenjang dan berkelanjutan agar mencapai sesuatu yang lebih baik dan lebih efektif. State of the art dalam penelitian ini adalah sebagai berikut :

Tabel 1. State of The Art

\begin{tabular}{|c|c|c|c|c|c|}
\hline No. & Tahun & Penulis & Judul & Jurnal & Temuan \\
\hline 1 & 2006 & Djoko Prakosa & $\begin{array}{l}\text { Menggagas pembelajaran } \\
\text { anatomi pada kurikulum } \\
\text { berbasis kompetensi dasar } \\
\text { unutk pendidikan } \\
\text { kedokteran dasar }\end{array}$ & $\begin{array}{l}\text { Jurnal } \\
\text { Anatomi } \\
\text { Indinesia }\end{array}$ & $\begin{array}{l}\text { Jurnal membahas } \\
\text { konsep dasar } \\
\text { kurikulun dalam } \\
\text { perkuliahan } \\
\text { anatomi }\end{array}$ \\
\hline 2 & 2016 & $\begin{array}{l}\text { Dini Indriyani } \\
\text { Putri }\end{array}$ & $\begin{array}{l}\text { Perencanaan aplikasi } \\
\text { multimedia untuk } \\
\text { pembelajaran anatomi } \\
\text { tubuh manusia untuk } \\
\text { sekolah dasar }\end{array}$ & $\begin{array}{l}\text { Jurnal } \\
\text { Teknologi dan } \\
\text { Sistem } \\
\text { Komputer }\end{array}$ & $\begin{array}{l}\text { Aplikasi } \\
\text { multimedia } \\
\text { dalam } \\
\text { pembelajaran } \\
\text { anatomi }\end{array}$ \\
\hline 3 & 2020 & Rusli Wanasuria & $\begin{array}{l}\text { Aplikasi pengenalan } \\
\text { anatomi tubuh manusia }\end{array}$ & $\begin{array}{l}\text { Jurnal Riset dan } \\
\text { Aplikasi Mahasiswa }\end{array}$ & $\begin{array}{l}\text { Aplikasi manusia } \\
\text { berbasis android }\end{array}$ \\
\hline
\end{tabular}

Dipublikasikan Oleh : 
METODE

Metode yang digunakan dalam penelitian ini dengan menggunakan metode kualitatif yaitu penelitian deskriptif kualitatif (Maolani, R. A., \& Cahyana, 2016) dengan menggunakan teknik survey. Teknik pengambilan sampel yang digunakan pada penelitian ini adalah teknik total sampling dimana populasi digunakan langsung sebagai sampel. Instrumen penelitian yang digunakan adalah angket, observasi, dan dokumentasi. Teknik analisis data yang menggunakan model Miles and Huberman. Aktivitas dalam analisis data kualitatif yaitu reduksi data, penyajian data, verifikasi data atau penarikan kesimpulan (Sugiyono, 2012).

Reduksi data dilakukan dengan membentuk forum diskusi (FGD) dengan rekan-rekan yang terlibat dalam penelitian baik secara langsung dan tidak langsung, serta kepada orang-orang yang dianggap ahli pada bidang penelitian ini. Hal ini bertujuan untuk mendapatkan hasil yang maksimal dan sesuai dengan data yang diperoleh dari lapangan. Reduksi dan penyajian data bertujuan untuk memudahkan peneliti dan tim untuk penarikan kesimpulan dari masalah yang terjadi dilapangan, kegiatan yang terkofigurasi dengan sistemasis dengan membahas dan menyimpulkan jalan keluar terhadap masalah yang terjadi. Diperlukan kesepakatan tim peneliti untuk mendapatkan kesimpulan yang sesuai dengan apa yang terjadi dilapangan.

Angket merupakan metode pengumpulan data yang dilakukan dengan cara memberikan seperangkat pertanyaan tertulis kepada reponden untuk diberikan respos dengan pengguna (Widoyoko, 2016). Angket yang diberikan dibagi menjadi empat variabel yang masing-masing variabelnya terdapat beberapa pernyataan yaitu variabel pendapat mahasiswa tentang daya tarik media berbasis aplikasi Anatomi Illustration selama perkuliahan, kemudahan penggunaan Anatomi Illustration dalam perkuliahan anatomi, efisiensi waktu penggunaan Anatomi Illustration selama perkuliahan, dan kemanfaatan dari media berbasis aplikasi Anatomi Illustration sebagai media ilustrasi, serta harapan tentang penggunaan Anatomi. Angket dilakukan secara online dengan menggunakan google form. Angket digunakan dengan tujuan mengetahui kekurangan dan kelebihan yang dirasakan oleh mahasiswa dalam melaksanakan perkuliahan anatomi dengan menggunakan bantuan media berbasis Aplikasi. Berikut kisi-kisi instrumen angket yang digunakan:

Tabel 2. Kisi-kisi Instumen Angket Respon Media Berbasis Aplikasi Anatomy Illustration

\begin{tabular}{cll}
\hline No. & \multicolumn{1}{c}{ Aspek yang Dinilai } & Item Pertanyaan \\
\hline 1 & Daya Tarik & $1,2,3$ \\
2 & Kemudahan Penggunaan & 4,5 \\
3 & Efisiensi Waktu & 6 \\
4 & Manfaat Media Berbasis Aplikasi Anatomy Illustration & $7,8,9$ \\
\hline
\end{tabular}

Pemberian skor angket respon mahasiswa dengan menggunakan skala penilaian sebagai berikut:

Tabel 3. Skala Penilaian Angket

\begin{tabular}{|c|c|}
\hline Alternatif Jawaban & Skor \\
\hline Sangat Setuju & 4 \\
\hline Setuju & 3 \\
\hline Tidak Setuju & 2 \\
\hline Sangat Tidak Setuju & 1 \\
\hline
\end{tabular}

Interpretasi validitas angket respon mahasiswa ditentuka dengan kriteria sebagai berikut.

Tabel 4. Kriteria Validitas Angket Respon Mahasiswa

\begin{tabular}{lcc}
\hline & Kriteria & Interpretasi \\
\hline $\mathrm{V}>0,667$ & & Tidak valid \\
$0,667 \leq \mathrm{V}$ & & Valid \\
\hline
\end{tabular}

Sumber: (Azwar, 2013)

Sebelum angket digunakan, dilakukan uji validitas untuk mengukur ketepatan di setiap butir pertanyaan. Uji validasi terdiri dari ahli bahasa, ahli media, dan ahli pendidikan. Setelah angket dinyatakan valid, selanjutnya angket respon diberikan kepada mahasiswa setelah perkuliahan dengan menggunakan media berbasis aplikasi Anatomy Illustration. Respon mahasiswa dapat diukur menggunakan angket dengan melihat banyaknya hasil respon positif atau negatif yang diberikan. Respon dikatakan bernilai positif jika mahasiswa merasa senang

Dipublikasikan Oleh : 
terhadap perkuliahan anatomy dengan menggunakan Anatomy Illustration, dan ketertarikan terhadap perkuliahan, begitu sebaliknya. Berikut kriteria respon mahasiswa pada tabel 5.

Tabel 5. Kriteria Respon Mahasiswa

\begin{tabular}{cc}
\hline Tingkat Pencapaian (\%) & Kategori \\
\hline $25 \% \leq \mathrm{P}<43 \%$ & Tidak Positif \\
$44 \% \leq \mathrm{P}<62 \%$ & Kurang Positif \\
$63 \% \leq \mathrm{P}<81 \%$ & Positif \\
$82 \% \leq \mathrm{P}<100 \%$ & Sangat Positif \\
\hline
\end{tabular}

Sumber: (Sudjana, 2011)

Rumus untuk menentukan persentase nilai respon mahasiswa (\% NRM) sebagai berikut:

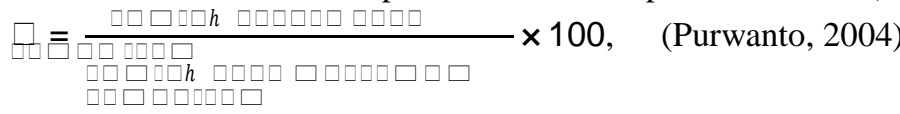

\section{HASIL DAN PEMBAHASAN}

Berikut hasil validasi terhadap angket respon mahasiswa menggunakan media berbasis aplikasi Anatomy Illustration dapat dilihat pada Tabel 6.

Tabel 6. Hasil Validitas Angket Respon Mahasiswa

\begin{tabular}{|c|c|c|c|}
\hline No. & Pernyataan & $\begin{array}{c}\text { Indeks } \\
\text { Validitas }\end{array}$ & Kategori \\
\hline 1 & $\begin{array}{l}\text { Angket respon mahasiswa memuat petunjuk pengisian yang } \\
\text { mudah dipahami. }\end{array}$ & 0,88 & Valid \\
\hline 2 & $\begin{array}{l}\text { Angket respon mahasiswa memuat pernyataan yang tepat dan } \\
\text { cukup untuk menilai aspek daya tarik dari media berbasis aplikasi } \\
\text { Anatomy Illustration. }\end{array}$ & 0,88 & Valid \\
\hline 3 & $\begin{array}{l}\text { Angket respon mahasiswa memuat pernyataan yang tepat dan } \\
\text { cukup untuk menilai efisiensi waktu dan kemudahan penggunaan } \\
\text { media berbasis aplikasi Anatomy Illustration. }\end{array}$ & 0,75 & Valid \\
\hline 4 & $\begin{array}{l}\text { Angket respon mahasiswa memuat pernyataan yang tepat dan } \\
\text { cukup untuk menilai kemanfaatan media berbasis aplikasi } \\
\text { Anatomy Illustration. }\end{array}$ & 0,75 & Valid \\
\hline 5 & $\begin{array}{l}\text { Angket respon mahasiswa memberi ruang bagi mahasiswa untuk } \\
\text { memberikan pesan dan kesan mahasiswa terhadap penggunaan } \\
\text { media berbasis aplikasi Anatomy Illustration. }\end{array}$ & 0,75 & Valid \\
\hline 6 & $\begin{array}{l}\text { Pernyataan pada angket respon mahasiswa menggunakan kalimat } \\
\text { yang mudah dipahami. }\end{array}$ & 0,88 & Valid \\
\hline 7 & $\begin{array}{l}\text { Pernyataan pada angket respon mahasiswa menggunakan bahasa } \\
\text { yang komunikatif. }\end{array}$ & 0,75 & Valid \\
\hline & Rata-rata Kevalidan & 0,80 & Valid \\
\hline
\end{tabular}

Berdasarkan hasil validasi di atas terlihat bahwa angket yang digunakan untuk angket respon mahasiswa valid dengan rata-rata kevalidan 0,80. Berdasarkan hasil validasi tersebut maka angket respon mahasiswa terhadap penggunaan media berbasis aplikasi Anatomy Illustration dapat digunakan.

Untuk indikator penilaian daya tarik berisikan tiga butir pertanyaan meliputi: 1) Perkuliahan dengan menggunakan media berbasis aplikasi Anatomy Illustration membuat saya termotivasi untuk belajar; 2) Perkuliahan dengan menggunakan media berbasis aplikasi Anatomy Illustration membuat perkuliahan Anatomi lebih menyenangkan; 3) Saya tidak cepat bosan selama perkuliahan menggunakan media berbasis aplikasi Anatomy Illustration. Berikut diagram hasil angket respon untuk indikator daya tarik. 


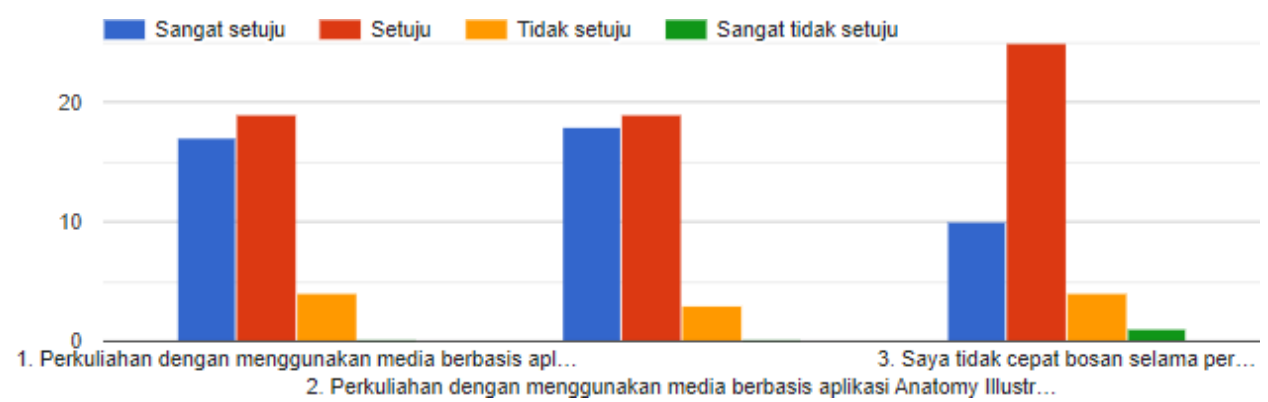

Gambar 4. Diagram Hasil Respon Mahasiswa Indikator Daya Tarik

Indikator kemudahan pengguna, peneliti memberika dua pernyataanterkai dengan kemuadahan penggunaan anatomy illustration kepada mahasiswa pada angket respon. Pernyataan yang diberikan meliputi mudah untuk digunakan dan mudah untuk dipahami. Berikut hasil respon mahasiswa untuk indikator kemudahan pengguna.

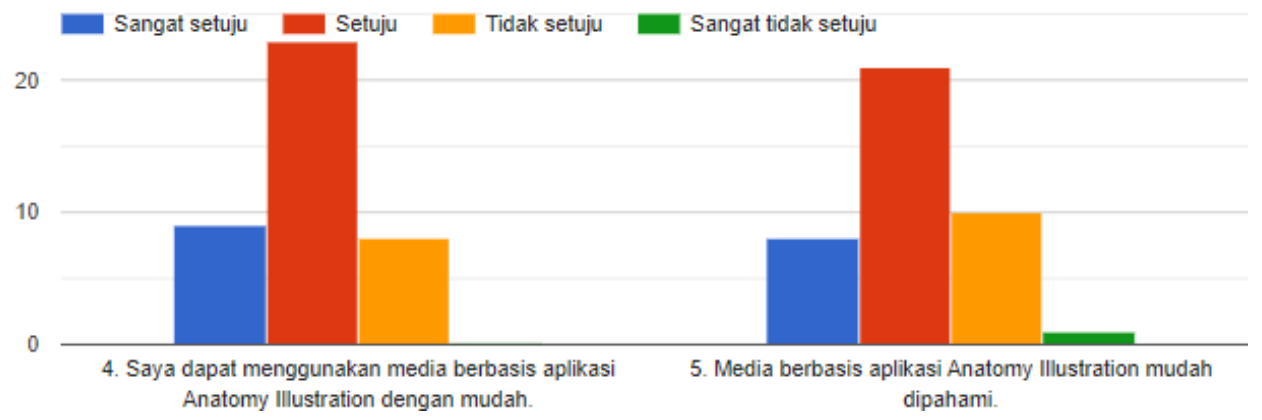

Gambar 5. Diagram Hasil Respon Mahasiswa Indikator Kemudahan Pengguna

Untuk indikator efisiensi waktu hanya diberikan satu butir pernyataan, dan hasilnya digambarkan pada diagram berikut.

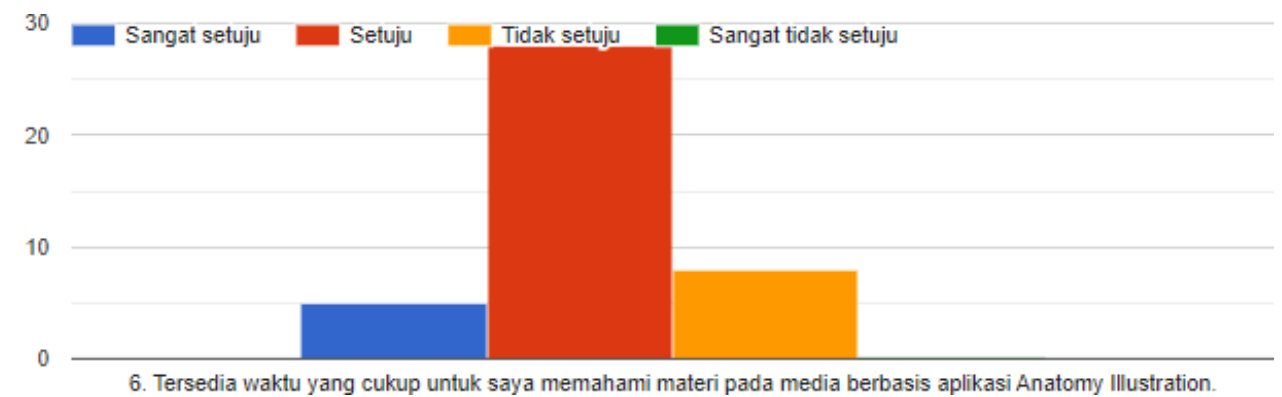

Gambar 6. Diagram Hasil Respon Mahasiswa Indikator Efisiensi Waktu

Sedangkan untuk indikator kemanfaatan, peneliti menyajikan tiga pernyataan, meliputi: 1) Perkuliahan menggunakan media berbasis aplikasi Anatomy Illustration dapat membantu saya dalam menghapal bagianbagian anatomi tubuh manusia; 2) Saya dapat belajar sesuai dengan kecepatan belajar saya; 3) Materi yang disajikan jelas dan dapat dipahami dengan mudah.

Dipublikasikan Oleh :

UPT Publikasi dan Pengelolaan Jurnal

Universitas Islam Kalimantan Muhammad Arsyad Al-Banjari Banjarmasin 


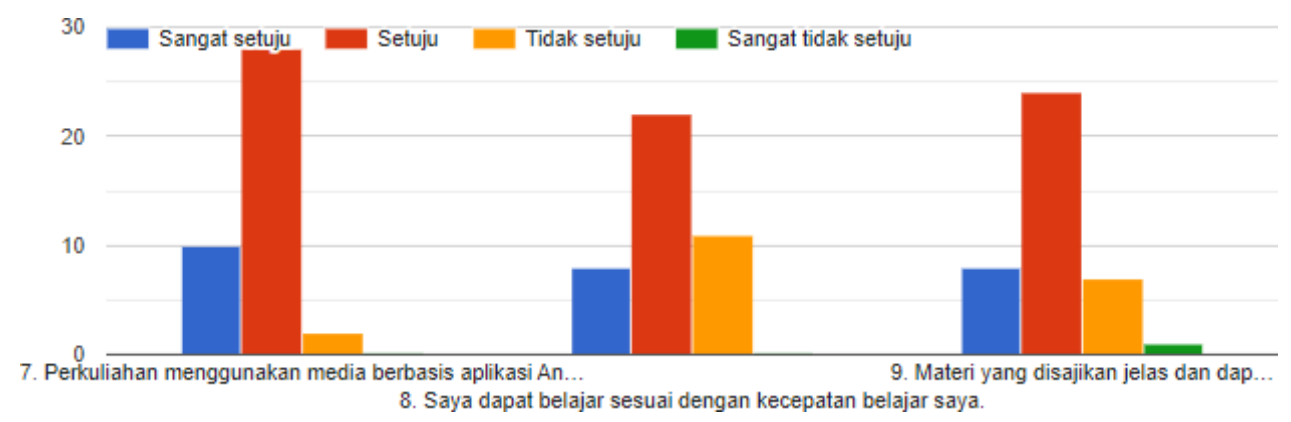

\section{Gambar 7. Diagram Hasil Respon Mahasiswa Indikator Manfaat Media Berbasis Aplikasi Anatomy Illustration}

Angket respon mahasiswa diberikan kepada mahasiswa semester 3 program studi pendidikan jasmani, kesehatan, dan rekreasi yang berjumlah 40 mahasiswa. Adapun hasil angket respon mahasiswa tehadap perkuliahan anatomi dengan menggunakan media berbasis aplikasi Anatomy Illustration saat covid-19 dapat dilihat pada tabel berikut.

Tabel 7. Hasil Angket Respon Mahasiswa

\begin{tabular}{clccc}
\hline No. & \multicolumn{1}{c}{ Aspek yang Dinilai } & Rata-rata & Persentase & Kategori \\
\hline 1 & Daya Tarik & 3,27 & $82 \%$ & Sangat Positif \\
2 & Kemudahan Penggunaan & 2,96 & $74 \%$ & Positif \\
3 & Efisiensi Waktu & 2,95 & $74 \%$ & Positif \\
4 & Manfaat Media Berbasis Aplikasi Anatomy Illustration & 3,04 & $76 \%$ & Positif \\
\hline & Rata-rata Keseluruhan & $\mathbf{3 , 0 6}$ & $\mathbf{7 6 \%}$ & Positif \\
\hline
\end{tabular}

Pada tabel 7 terlihat bahwa rata-rata respon mahasiswa terhadap media berbasis aplikasi Anatomy Illustration pada perkuliahan Anatomi adalah 76\%. Jadi, dapat disimpulkan bahwa media berbasis aplikasi Anatomy Illustration memberikan respon positif untuk perkuliahan anatomi.

Observasi difokuskan untu melihat apakah perkuliahan telah sesuai dan untuk mengidentifikasi kendalakendala yang dialami selama proses perkuliahan anatomy menggunakan media berbasis aplikasi Anatomy Illustration. Pada penelitian ini, peneliti menggunakan bantuan dua orang observer yang bertugas untuk mengamati keberlangsungan perkuliahan yang sedang berlangsung pada setiap pertemuan. Hasil analisis terhadap lembar observasi dijadikan salah stau pertimbangan dalam menentukan nilai suatu media pembelajaran.

\section{PENUTUP}

Berdasarkan penelitian yang telah dilakukan, disimpulkan bahwa perkuliahan Anatomi menggunakan media berbasis aplikasi Anatomy illustration saat Covid-19 memberikan respon sangat positif ditinjau dari aspek daya tarik (82\%), positif ditinjau dari aspek kemudahan penggunaan (74\%), positif ditinjau dari aspek efisiensi waktu (74\%), dan positif ditinjau dari manfaat dari media berbasis aplikasi Anatomy Illustration (76\%). Kesimpulan dari penggunaan media berbasis aplikasi Anatomy Illustration adalah memberikan respon positif untuk perkuliahan anatomi.

\section{REFERENSI}

Arsyad, A. (2011). Media Pengajaran. Jakarta: PT. Raja Grafindo Persada.

Asyura, I., \& Dewi, R. (2020). Analisis Kemampuan Matematis Mahasiswa PGSD Terhadap Penggunaan Geogebra Classroom di Era dan Pasca Pandemi COVID-19. Jurnal Cendekia: Jurnal Pendidikan Matematika, 4(2), 976-989. https://doi.org/10.31004/cendekia.v4i2.325

Azwar, S. (2013). Validitas dan Reliabilitas. Yogyakarta: Pustaka Pelajar.

Depdikbud, P. B. (2016). Kamus Besar Bahasa Indonesia (Edisi Kelima). Balai Pustaka.

Khilmi, D., Firdausi, A., Lestari, N., Sari, K., Sagita, P., Cahyati, C., Prasetio, R., \& Irawan, D. (2021). Tingkat Kecemasan dan Motivasi Atlet Basket Bangka Belitung Saat Menjelang Pertandingan. Jurnal Riyadhoh: Jurnal Pendidikan Olahraga, 5(1), 10-16.

Mahnun, N. (2012). Media Pembelajaran (Kajian terhadap Langkah-langkah Pemilihan Media dan Implementasinya dalam Pembelajaran). An-Nida', 37(1), 27-35.

Dipublikasikan Oleh :

UPT Publikasi dan Pengelolaan Jurnal

Universitas Islam Kalimantan Muhammad Arsyad Al-Banjari Banjarmasin 
Maolani, R. A., \& Cahyana, U. (2016). Metodologi Penelitian Pendidikan. Jakarta: PT. Raja Grafindo Persada. Miharja, F. J. (2015). Development of Module Human Anatomy and Phisiology with Problem Based Learning to Improve Student Competence at Study Program Biology Education. Prosiding Seminar Nasional Pendidikan Biologi, 1974, 220-227.

Pearce, E. C. (2016). Anatomi dan fisiologi untuk paramedis. PT Gramedia Pustaka Utama.

Purwanto, N. (2004). Prinsip-prinsip dan teknik Evaluasi Pendidikan. Bandung: Remaja Rosdakarya.

Putri, D. I., Isnanto, R. R., \& Martono, K. T. (2016). Perancangan Aplikasi Multimedia untuk Pembelajaran Anatomi Tubuh Manusia untuk Sekolah Dasar. Jurnal Teknologi Dan Sistem Komputer, 4(1), 124. https://doi.org/10.14710/jtsiskom.4.1.2016.124-132

Riduwan. (2012). Pengantar Statistika Sosial. Bandung: Alfabeta.

Sudjana, N. (2011). Penilaian Hasil dan Proses Belajar Mengajar. Rosda Karya.

Sugiyono. (2012). Metode Penelitian Pendidikan: Pendekatan Kuantitatif, Kualitatif, dan R\&D. Bandung: Alfabeta.

Wahyuningsih, H. P., \& Kusmiyati, Y. (2017). Anatomi Fisiologi. Cetakan Pe. Kementrian Kesehatan Republik Indonesia.

Wanasuria, R., Ismawan, F., \& Heriyati, H. (2020). Aplikasi Pengenalan Anatomi Tubuh Manusia Berbasis Android. Jurnal Riset Dan Aplikasi Mahasiswa Informatika (JRAMI), 1(01), 59-65. https://doi.org/10.30998/jrami.v1i01.185

Widoyoko, E. (2016). Penelitian Hasil Pembelajaran Di Sekolah. Yogyakarta: Pustaka Pelajar. 